\title{
Adam Smith Would Decry President Bush's Hubris and Business Education
}

\author{
Yoshi TSURUMI \\ (City University of New York)
}

\begin{abstract}
President George W. Bush is the first president of the U.S. with a Master's of Business Administration (MBA). Yet, he epitomizes the worst aspects of America's business education. To privatize Social Security, he is peddling a colossal lie about its solvency. It is the propaganda of lying, not personal integrity, that counts in his presidency. Business education has also produced Enron's Jeff Skilling (Harvard MBA) and other MBAs behind the malfeasances of Tyco, HealthSouth, Haliburton, AIG, and WorldCom. Many executives of Corporate America who hold MBAs have also been engaged in the unethical acts of raiding their corporate treasuries at the expense of employees and stockholders. President Bush and the business aristocrats show no compassion for working Americans, robbing them to benefit big business and the very rich. Last year, due to Bush tax cuts, over 80 of America's most profitable 200 corporations did not pay even a penny of their federal and state income taxes. Meanwhile, to pay for his additional tax cuts for the very rich, President Bush is drastically cutting the federal lunch programs for poor children.
\end{abstract}

Emulating President Bush's hubris, one CEO after another of Corporate America give themselves obscenely large bonuses that have little to do with their performance. To pay for such self-dealt compensations, corporate aristocrats lay off their workers, cut ordinary employees' health benefits, and outsource jobs abroad. Under the Bush Administration, over 5 million Americans have lost their health benefits and America has lost over 2.7 million quality manufacturing jobs. In 1980, the CEOs of Fortune 500 large corporations received, on average, 70 times larger annual compensations than their average employees. Under the Bush Administration, comparable CEOs have come to give themselves 600 to 1,000 times larger annual compensations than their rank-and-file employees whose pay has stagnated. President Bush and his rapacious "captains of piracy" of Corporate America are destroying America's democracy built up since Franklin D. Roosevelt's “New Deal” era. No wonder that other nations do not trust President Bush's promised democracy for Iraq.

Thirty years ago, President Bush was my student at Harvard Business School. In my class, he called Roosevelt a "socialist" and was against Social Security, unemployment insurance, Securities and Exchange Commission and other New Deal innovations. He refused to understand that capitalism becomes corrupt without democratic civic values and ethical restraints.

In those days, George W. Bush belonged to a minority of MBA students who were seriously disconnected from taking the moral and social responsibility for their actions. Today, he would fit in comfortably with an overwhelming majority of business students and teachers whose role models are celebrated captains of piracy. Since the 1980's, as neo-conservatives captured the Republican Party, America's business education has also increasingly become contaminated by the robber baron culture of the pre-Great Depression era. You won't hear such things as high purpose, honor, compassion and ethical leadership discussed at business schools.

Meanwhile, American economics study has increasingly become a pseudoscience of mathematical formula manipulation that is devoid of humanity. This economics has conquered America's business education and become fused with the robber baron culture of greed supremacy. American MBA's are taught to treat ordinary employees as disposable costs and to swallow uncritically the gospel that corporations exist only to reward abstract stockholders. MBA's are taught the pretend-science of manipulating accounting, finance, employees, customers, and stock prices. Financial 
games and hostile takeovers of competitors are taught to accomplish corporations' sole objective - to make money and manipulate stock prices. Such a mistaken view of corporations has caused the dismal decline of American auto manufacturers while Toyota and Honda widen their market shares and profits in America, pursuing their goals of expanding employment and technological innovations.

To justify the robber baron culture, America's business educators and economists falsely cite their demigod of laissez-faire market economics, Adam Smith. Little do they know that Adam Smith in fact scathingly castigated the Bush type of government-business collusion and unfair taxes, Wal-Mart's exploitations of labor and communities, and robber barons' hubris. No where in his 900-page book, The Wealth of Nations, does Adam Smith even imply that those who knowingly harm others and society in their pursuit of personal greed also benefit their society. He rejects the notion that a corporation exists to make money without ethical constraints.

Yoshi Tsurumi, Professor of International Business, Baruch College, the City University of New York. Tel: 646-312-3286. E-Mail: yoshi_tsurumi@baruch.cuny.edu 17 Lexington Avenue, New York, N.Y. 10010.

(March 22, 2005) 